This is the post print version of the article, which has been published in Social Indicators

Research. 2018, 137(3), 1091-1118.

http://dx.doi.org/10.1007/s11205-017-1611-7

[C] This document has been downloaded from TamPubuta.fi

Country-level investment in cultural opportunity structures. A potential source of health differences between 21 European countries

Leena K Koivusilta*, University Consortium of Seinäjoki, Faculty of Social Sciences, University of Tampere, Seinäjoki, Finland

Corresponding author:

* Corresponding author: University Consortium of Seinäjoki, FIN-60320 Seinäjoki, Finland, tel.

+358-50-345 2157, e-mail: leena.koivusilta@uta.fi

Corresponding author:

* Corresponding author: University Consortium of Seinäjoki, FIN-60320 Seinäjoki, Finland, tel.

+358-50-345 2157, e-mail: leena.koivusilta@uta.fi 


\begin{abstract}
Individual's participation in cultural activities may positively affect health through a pathway mediated by social capital. We examine whether country-level investment in cultural opportunity structures was associated with between-country differences in self-rated health and, if so, whether these associations were mediated by citizens' confidence in societal institutions, i.e., by institutional trust, regarded as a dimension of social capital. For 24,887 respondents in the European Social Survey, 2006, data on self-rated health, institutional trust (individual-level and country-level), and sociodemographic variables were linked with statistics-based country-level data on 10 indicators of cultural opportunity structures and mediator variables (gross domestic product (GDP), Gini index, and welfare state regime). Over and above the sociodemographics, six cultural indicators contributed to between-country health differences in logistic multilevel regression analysis: the percentage of arts students, the RC index, the percentage of writers and creative artists of total employment, exports of cultural goods, imports of cultural goods, and the number of feature films produced per capita. Controlling, furthermore, for trust, and country-level mediators, only imports of cultural goods contributed to between-country differences in health. No associations with other cultural indicators remained after controlling for GDP or welfare state regime. Institutional trust may partially mediate the significance of cultural investments for self-rated health. However, both cultural investment and trust may be concomitants of general prosperity and welfare policies. Future studies should investigate whether the countries' welfare policies influence the transformation of cultural investment into institutional trust and which types of indicators best depict associations between investments and health.
\end{abstract}

Keywords: cultural opportunity structures, self-rated health, social capital, institutional trust, health differences 


\section{Country-level investment in cultural opportunity structures. A potential source of health differences between 21 European countries}

\section{Introduction}

Studies using a variety of research designs and indicators have shown that participation in cultural or artistic activities is associated with various dimensions of physical and self-rated health status (Bygren et al. 2009a; Cuypers et al. 2012; Konlaan 2001; Nenonen et al. 2014; Nummela et al. 2008a; Wilkinson et al. 2007; Windsor 2005), life expectancy (Bygren et al. 2009b; Konlaan et al. 2000; Väänänen et al. 2009), and general quality of life (Bowling and Zahava 2004; Jensen 2013; Khawaja and Mowafi 2007; Kilroy et al. 2007). For instance, such activities as singing in a choir or attendance as a spectator or a listener at cultural events seem to positively affect well-being and mood (Clift and Hancox 2010; Cuypers et al. 2012), and listening to music may speed up recovery from severe illnesses (Särkämö et al. 2013). Cultural participation has also been found to reduce the need for medication and medical services (Cohen et al. 2006; 2009; Staricoff 2004). Among the positive influences are certain biomedical determinants of health, such as blood pressure, adrenaline, or prolactin levels (Konlaan 2001; Staricoff 2004). However, populations with more community participation have been shown to have better health and longer life expectancy than those with less participation (Hyyppä and Mäki 2001), also after controlling for lifestyle and health risk factors (Cuypers et al. 2012; Hyyppä et al. 2006).

Naturally, the direction of the association may also be reversed, because a sufficient level of health and physical and psychosocial functioning is needed to enable participation. Various society-level and environmental factors may lead to less participation among people with physical disabilities, e.g. those using wheel-chairs (Smith et al. 2016), or those with problems in communication (Balandin 2011), or intellectual disabilities (Verdonschot etl al. 2009). Additionally, in general populations of working-aged people, such common health conditions as lower back pain may restrict both physical and psychosocial participation (Janowski et al. 2010), and some rather common mental illnesses, such as bipolar disorder, with a related stigma or self-stigmatization, may reduce social functioning (Latalova et al. 2013). Low social positions with insufficient economic resources among people with poor health (e.g. Bartley 2004) may further reduce readiness for participation. Altogether, neither the directions of associations nor the mechanisms linking together cultural participation and health are sufficiently transparent, nor are the society-level structures which make participation possible.

One factor influencing cultural activities is the organization and supply of these within countries, the socalled cultural opportunity structures. The framework for these is created by cultural policies and the organization of culture-related institutional structures (e.g., the supply of arts education or support to artistic work). Differences in these between European countries become obvious by looking at the considerable variations in public investments in culture (Council of Europe 2009). One hypothetical pathway, through which these structures that form a basis for participation might impact the health of individuals is social 
capital (e.g. Hyyppä and Mäki 2003). It is a resource created in a social or societal context, observed either as a characteristic of an individual or of a group of people. Social networks, shared norms, and feelings of reciprocity or trust all reflect social capital and make it easier for individuals or groups to operate within the social structure (Coleman 1988). It has even been recognized as a key component in building and maintaining a democracy (Putnam 2000). Robert Putnam (2000) posits that social capital consists of two components, bonding and bridging capital, the former referring to networks within socially homogeneous groups and the latter to networks among heterogeneous groups. (Putnam 2000.) A wealth of opportunities for cultural participation in a society might advance both types of social capital through the possibilities of sharing experiences and increasing understandings among people holding different worldviews. However, social capital shared in a homogeneous group may also act negatively to exclude outsiders (Portes 1998). This might take place if cultural opportunity structures are constructed in ways, which strengthen barriers between activities typical of elites and those practiced among "common people” (see Bourdieu 1986).

Studies using different methodologies and indicators have illuminated positive associations between social capital and health (Abbott and Freeth 2008; Giordano and Lindström 2010; Islam et al. 2006; Kim et al. 2006; Habibov and Afandi 2011; Nieminen et al. 2010; Nummela et al. 2008b; Schultz et al. 2008; Subramanian et al. 2002). Social capital seems to also influence health-promoting behaviors (Bolin et al. 2003; Lin 2001). As the dimension of social capital, this research concentrated on trust - more specifically on institutional trust, which means a person's confidence in the trustworthiness of the important governmental and political institutions in his or her own country or internationally (see Harteveld et al 2013; Rothstein and Stolle 2003). Associations between trust and subjective health have been observed in many studies (Campos-Matos et al. 2015; Helliwell and Putnam 2004; d’Hombres et al. 2010; Jen 2010; Kim et al. 2011; Snelgrove et al. 2009), but there are also exceptions (Poortinga 2006b; Veenstra 2005). In research, trust has typically been measured as (generalized or interpersonal) trust or reliance on others (see Putnam 2000) and more seldom as institutional trust (Ahlquist et al. 2008). Yet, trust in a society’s institutions, particularly those directly relevant to health, has been associated with an individuals' health (Mohseni and Lindström 2007) and with discrimination on grounds of illness (Zoppei et al. 2014).

Institutional trust may be linked with health in differing ways depending on whether observed on country-level or experienced by individuals. On country-level, it may be related to generally shared confidence in the health care or social security system, and to the society's ability to maintain safety and predictability of life. These may be particularly important for some vulnerable segments of the population, such as the poor or people experiencing otherwise harsh circumstances. In societies with low levels of trust, an ethos of the obligation to fend for oneself rather than to rely on the system may burden whole population groups. People in high-trust societies may also feel they have more control over their lives and have stronger incentives to participate in political processes, e.g., those influencing health policies (see Habibov and Afandi 2011). On individual-level, one element in trust is the perception of procedural justice, a faith in being fairly treated by authorities (Hough et al. 2013). This may add to a person's compliance with following the recommendations of medical personnel or pursuing healthy lifestyles (Ahlquist et al. 2008; Mmari et al. 
2016; Tyler et al. 2013). Low levels of institutional trust may worsen health through psychosocial processes (i.e., stress-related) or behavioral pathways. Norms, values, and attitudes emphasizing health-enhancing behaviors might spread more rapidly in trustful societies in which social control acts in constructive ways (Kawachi and Berkman 2000). The diffusion of health information may be fast, while in low-trust societies the introduction of preventive health policies may be slower (Ahlquist et al. 2008).

In general, countries with stable democracies and effective and fair political and governmental organizations (Inglehart 1997; Rothstein and Stolle 2003) with less poverty (Franzini et al. 2005) or with less income inequality (Rözer and Volker 2016; Wilkinson 2000) often are characterized by populations that have more trust. Those countries may end up in a consensus regarding greater investments in cultural services and other structures for building social capital. Here, also the role of various welfare policies pursued in countries is obvious; countries belonging to different welfare regimes have been found to differ according to general health levels of their citizens (Mackenbach et al. 2013), health inequality between socioeconomic groups (Eikemo et al. 2008) and also according to various forms of social capital, institutional trust included (e.g. Rostila 2013). Thus, in well-functioning societies, political decisions made about cultural policies may concurrently be both creators of social capital and also indicators of social capital that already prevails in a society.

Although social capital on micro-level (individuals, subgroups of populations) is required in building institutions (Fukuyama 2002), the roles of macro- or meso-level actors, such as public institutions or activities on governmental or community level, in the creation of social capital have been discussed (Bowles and Gintis 2002; Heller 1996). Lowndes and Wilson (2001) criticized the social capital perspective for undervaluing the role of the state, government and political factors in providing opportunities for social participation. These authors argued that "the underlying institutional framework is a crucial factor in determining the long-term prospects for social capital in any society” and emphasized the important role of the government in 'framing' civil society. According to these authors, governance affects not only how much participation is possible but also for whom it is possible, i.e., the distribution of opportunities to participate among social groups (Lowndes and Wilson 2001). The emphasis in their analysis was at the local level, but the arguments might apply to state level governance as well. Thus, the term "political opportunity structure” that was used by Maloney and colleagues (2000) to refer to the role of institutions in creating an infrastructure in which people could network might also frame a society's cultural opportunity structure. Maloney and co-authors criticize Putnam for neglecting the role played by political structures and institutions in "shaping the context of associational activity" and hence the creation of social capital (Maloney et al. 2000).

In health research, cultural activities have often consisted of myriad ways of "doing things together”. Self-reported frequencies of participation, such as singing in a choir or going to theatre, have been investigated. On the macro- or meso-level, statistics on attendance at art exhibitions and concerts within countries or regions have been examined. As our emphasis is on country-level factors structuring the opportunities for cultural participation, indicators measuring investment in various types of cultural 
infrastructure, including education, goods or equipment are used. We subscribe the wide UNESCO definition of culture as "the set of distinctive spiritual, material, intellectual and emotional features of society or a social group, that encompasses, not only art and literature, but lifestyles, ways of living together, value systems, traditions and beliefs” (UNESCO Institute for Statistics 2001). Because of difficulties in directly measuring beliefs and values, the definition was further refined to include "the measurement of the behaviors and practices resulting from the beliefs and values of a society or a social group.” (UNESCO Institute for Statistics 2009). In this framework, both the social dimension of culture, including cultural participation and cultural heritage, have been included, in addition to the economic dimension of investment in elements of cultural infrastructures, such as education.

The construct of social capital, particularly its dimension of institutional trust, serves here as a hypothesized mechanism linking the created cultural opportunity structures with health. The idea is that country-level investment in culture may create circumstances or a "general cultural atmosphere" in which trust in institutions can easily develop (see von Brandenburg 2008; Mills and Brown 2004), and trust then may have an impact on people's health. The objective was, thus, to study whether country-level investment in creating opportunities for participation in cultural activities was related to the self-rated health of citizens in European countries and whether the association was mediated by the level of social capital - as indicated by its dimension of institutional trust.

\section{Materials and methods}

\subsection{Study design and data collection}

The baseline data came from the third wave of data collection (in 2006) of the European Social Survey (ESS) and consists of 43000 respondents in 23 countries (European Social Survey 2008). Random samples with comparable estimates based on full coverage of the eligible residential populations aged $15+$ years were based on the same principles of probability and representativeness in all participating countries. A total of 24 887 working-age, i.e., 25-65 year-old, respondents from 21 countries were included in the data for this study. Two countries (2645 respondents aged 25-64 years) were excluded from the data because of missing information on the country-level indicators. Of the 24887 respondents, 24280 were available in the sample after deleting cases list-wise by each variable in the analysis ( $97.6 \%$ of the original sample for the included age groups).

For each person, cultural statistics describing the country he or she came from were linked to the baseline data record. Cultural statistics in the European countries were available, collected in congruent ways by Eurostat, UNESCO, and Council of Europe. The set of countries included in the survey was restricted by the availability of relevant country-level cultural data on the Internet; certain relevant data were not available 
for all indicators from all countries participating in the ESS, which meant making compromises to obtain a wide variety of statistics from as many countries as possible. The 21 countries included in the analysis were Austria (AT), Belgium (BE), Bulgaria (BG), Cyprus (CY), Denmark (DK), Estonia (EE), Finland (FI), France (FR), Germany (DE), Hungary (HU), Ireland (IE), the Netherlands (NL), Norway (NO), Poland (PL), Portugal (PT), Slovakia (SK), Slovenia (SI), Spain (ES), Sweden (SE), Switzerland (CH), and the United Kingdom (GB). (The countries excluded were the Russian Federation and Ukraine).

\subsection{The dependent variable}

Self-reported general health status was asked in the ESS as "How is your (physical and mental) health in general?” The eligible responses included 'very good', 'good', 'fair', 'bad' and 'very bad'. The five point measure of self-rated health has been regarded as a good proxy for such more objectively measured dimensions of health, as assessed as a physician, as chronic diseases, mortality, morbidity and the level of healthcare utilization (Idler et al. 2000; Idler and Benyamini 1997; Lindström et al. 2004; Lopez 2004; Miilunpalo et al. 1997; Mohseni and Lindström 2007). Individual self-rated health is strongly connected to several individual-level socio-demographic characteristics, including age and gender (Kawachi et al. 1999), socioeconomic status measured as educational level (Jürges et al. 2008; Miech and Hauser 2001), labor market position (Aittomäki et al. 2010), income level (Aittomäki et al. 2010; Fritzell et al. 2004; Link et al. 2008), and whether a person is living alone or in a relationship with a partner (Joutsenniemi et al. 2006).

For the analysis, the categories were dichotomized following the prevailing tradition in health inequality research (e.g. Manor et al. 2000): good (combining categories very good, good), other (combining categories fair, bad, very bad).

\subsection{Independent variables}

\subsubsection{Individual-level explanatory variables}

Participation in cultural activities is structured by socio-demographic factors (Chan and Goldthorpe 2010; Pampel 2006), with the middle classes possessing the most social (as well as economic and cultural) capital needed for participation (e.g., Bourdieu 1984). State-level opportunities for cultural participation may be distributed in the same way, and to answer the question about whether state-level cultural investments have an impact on health over and above socioeconomic factors, a multilevel statistical analysis can be applied (Raudenbush and Bryk 2002). There is also some indication that indicators of social capital may be associated with health independently of individual-level factors (Dahl and Malmberg-Heimonen 2010; 
Habibov and Afandi 2011; Nieminen et al. 2013). To take account of these possibilities, these socioeconomic variables were used:

Age of the respondent: The working-age population from 25 to 64 years was included in the study. The extremes of the distribution were omitted because the question about self-rated health is known to be strongly dependent on age (Eriksson et al. 2000).

Gender: male, female

Education: Years of completed fulltime education. Some single extreme values were included in this variable, and they were not omitted from the analysis.

Main activity during the last seven days: paid work, unemployed or not in the labor force (either looking for a job or not / permanently sick or disabled, retired); housework or other (including looking after children, others / education, community or military service, other).

Legal marital status: Married or in a civil partnership, separated or widowed (includes the categories still legally married, separated and still in a civil partnership, divorced, formerly in a civil partnership now dissolved / formerly in civil partnership and partner died); never married or never in civil partnership.

Social capital was indicated using a variable measuring institutional trust, or rather "confidence”, (see Kouvo 2011; Sztompka 1999) in various societal institutions within a country or internationally (Freitag 2003; Harteveld et al. 2013). The variable was constructed from seven items in the question, which asked the respondent to score the answers to the following questions, on a scale ranging from 0 (no trust at all) to 10 (complete trust), “... how much do you personally trust each of these institutions“ (country's parliament, the legal system, the police, politicians, political parties, the European Parliament, the United Nations) read out by the interviewer. A summary variable was formed using these items. The Cronbach’s alpha was 0.890 in the material that combined all countries.

\subsubsection{Country-level cultural variables}

In the UNESCO framework for cultural statistics, several cultural domains are separated based on mutually exclusive types of cultural activities, goods and services (e.g., music is separated from crafts). With data coming from several sources in this research, no division into domains could be made. In addition, the data were not divided into economic and social dimensions (UNESCO Institute for Statistics 2009) because of the poor availability of data on the social dimension, i.e., on cultural participation and attendance at various cultural or related (recreational or leisure) activities; data on attendance covering all the studied countries were reported for cinema attendance only. Thus, all data used in this study represented the economic dimension, and the indicators that were used measured productive cultural activities and cultural products, investments in cultural products, international cultural trade, cultural employment, and, in addition, education on fields related to culture. The cultural indicators used in this study were as follows: 
UNESCO World Heritage sights: The number of European cultural sites on the UNESCO World Heritage List per 100000 population in 2007. (Eurostat 2007).

Capitals of culture: Number of European capitals of culture per 100000 population in 1985-2013 (Eurostat 2011).

Cultural employment: Cultural employment as a portion of total employment (\%) in 2005 (Eurostat 2007).

Writers and creative artists: Percentage of writers and creative artists or performing artists of total employment in 2009 (Eurostat 2011), including authors, journalists, sculptors, painters, composers, musicians, singers, choreographers, dancers, actors, directors and other related artists.

Arts students: Tertiary students studying the arts, as a percentage of all students in 2007/2008 (Eurostat 2011). Fields of study in the arts include fine arts, music and performing arts, audio-visual techniques and media production, design, and craft skills.

Feature films: Total number of national feature films (fictional, animated, documentary) produced per 100000 population in 2006 (UNESCO Institute for Statistics 2011). A feature film is defined as at least 60 minutes long and intended for commercial exhibition in cinemas (UNESCO Institute for Statistics 2012). Data on film production are produced biennially to monitor global trends and assess cultural (e.g., linguistic) diversity in cinema (UNESCO Institute for Statistics 2013).

Cultural services: Harmonized indices of consumer prices for main cultural goods and services in 2010, including cinemas, theatres, concerts, museums, zoological gardens and the like, television and radio taxes and hire of equipment, other services (Eurostat 2011).

$R C$ index: European recreation and culture expenditure index in 2005. Based on real expenditures per capita on GDP at average OECD PPP (purchasing power parities) prices (USD) (Council of Europe/ERICarts 2011).

Exports of cultural goods: Exports of cultural goods (total core) in thousands of US dollars per population in 2002. The total score consists of summarizing exports of heritage goods, books, newspapers and periodicals, other printed material, recorded media, visual arts, and audiovisual media (UNESCO Institute for Statistics 2005).

Imports of cultural goods: Imports of cultural goods (total core) in thousands of US dollars per population in 2002. The same items are included in the total core as listed above (UNESCO Institute for Statistics 2005).

\subsubsection{Country-level mediator variables}

The variable described above (in 2.3.1) as social capital (measured as institutional trust) was also used as calculated at the country level to study its role as a mediator between self-rated health (on a personal level) and the country-level cultural variables. 
In research on country-level investment, the level of the economic development of the countries should be accounted for. Globally, the field of production at the crossroads between the arts, business and technology - the so-called "creative industries" - is estimated to account for more than 7 percent of the world's gross domestic product (United Nations 2004). Gross domestic product (GDP), calculated per inhabitant in 2009 (Euros), was used to represent the economic performance of the countries (Eurostat 2011).

To account for the possible impact of economic inequality in a country on people's health (e.g. Pickett and Wilkinson 2015), Gini index of equalized disposable income in 2009 was used (Eurostat 2015).

Type of welfare state regime has been found to be related to health inequalities between countries (e.g. Eikemo et al. 2008). Following Eping-Andersen (1990) and Ferrera (1996), the countries were classified as: Scandinavian (DK, FI, NO, SE), Anglo-Saxon (GB, IE), Bismarckian (AT, BE, CH, GE, FR, NL), EasternEuropean (BG, EE, HU, PL, SI, SK), and Southern (CY, ES, PT) regime. (BG, CY,EE, and SK were not included in the above mentioned classifications.)

All variables are described in Table 1.

--- Table 1. here ---

\subsubsection{Correlations between the country-level variables}

Spearman correlation coefficients between the country-level variables were calculated to describe how distinct or overlapping they were. The magnitudes of the coefficients were interpreted using the rule of thumb by Hinkle et al. (2003): $\rho \geq .90$ is "very high", .70 $\rho<.90$ "high", $.50 \leq \rho<.70$ "moderate", $.30 \leq \rho<.50$ "low", and a $\rho$ smaller than. 30 is "negligible". Among the cultural variables, the positive correlations were high between imports and exports of cultural goods, between imports of cultural goods and the RC index, and between the RC index and the percentage of writers and creative artists (Table 2). Correlations were moderate between exports of cultural goods and the RC index, between the percentage of writers and creative artists and the proportion of cultural employment from total employment, between exports of cultural goods and the percentage of writers and creative artists, between the numbers of feature films and UNESCO world heritage sights, between imports of cultural goods and the percentage of writers and creative artists, between the RC index and cultural employment, between imports of cultural goods and the percentage of arts students, and between exports of cultural goods and cultural employment. Imports of cultural goods had low correlations with the number of feature films and cultural employment, while exports of cultural goods had a low correlation with the percentage of arts students. The percentage of arts students also had a low correlation with cultural employment, the number of feature films, the RC index, and the number of UNESCO world heritage sites. Cultural services also had a low correlation with the number of capitals of culture. Altogether, the number of capitals of culture, cultural services, and UNESCO world heritage sites were the indicators most weakly associated with the other ones. 


\section{--- Table 2. ---}

Institutional trust didn't have a high correlation with any of the cultural indicators, but it had a moderate positive correlation with the percentage of writers and artists, with imports of cultural goods, with the RC index, with cultural employment, and the number of feature films (Table 2). It also had a low correlation with exports of cultural goods, with the proportion of UNESCO world heritage sites, and the percentage of arts students. Institutional trust had negligible correlations with the number of capitals of culture and with cultural services. The positive correlation of GDP was very high with imports of cultural goods, high with the RC index, with exports of cultural goods, with the proportion of writers and artists, and with institutional trust. GDP was moderately correlated with cultural employment and had low correlations with the percentage of arts students and the number of feature films. GDP had negligible correlations with the numbers of UNESCO world heritage sites and capitals of culture, as well as with cultural services. Gini index had low negative correlations with the number of capitals of culture, with the proportion of writers and creative artists, and with institutional trust. It had a low positive correlation with the percentage of arts students.

\subsection{Statistical analysis: fitting the multilevel models}

Due to the hierarchically nested structure of the data (individuals nested within countries), multilevel models were fitted to study the relative significance of individual-level and country-level explanatory variables for the individually measured and binary coded dependent variable (see Hox 2002). As the first step of the multilevel analysis, the variation in the dependent variable was studied without using any explanatory variables (the "empty" model, the intercept-only model or the variance component model) to decompose the variance of the intercept into variance components for both levels (Table 2, Model 0). Second, two models were fitted with all the individual-level socio-demographic variables fixed to show how the dependent variable varied according to these attributes (Table 2, Model 1). Third, the country-level cultural variables were added one at a time in Model 1 to study whether they contributed to explain self-rated health over and above the individual-level socio-demographic variables (Models 2). Furthermore, trust measured both on the individual and country levels was included in the models already including a statistically significant cultural variable to determine whether its association with self-rated health was accounted for by trust. Finally, the associations in each of the versions of Model 3 were controlled for GDP, the Gini index, and the welfare state regime (these taken one at a time).

Associations were expressed as odds ratios (OR) and their 95\% confidence intervals (CI). At each stage of the multilevel analysis, intra-class correlation coefficients (ICC) were calculated to describe the percentage of total variation in the dependent variable that was attributable to the context being modeled, i.e., 
the country. The higher the ICC, the more important the context is for understanding variation in the individual outcomes under investigation (Merlo et al. 2009). All analyses were performed using the Stata statistical program version 14 (xtmelogit command; maximum likelihood estimates). Only those individuals were included in the analysis who yielded data on all variables ( $96.7 \%$ of the original sample).

\section{Results}

\subsection{Multilevel models for self-rated health}

The empty variance-component model fitted in the data revealed that $90.35 \%$ of the total variance of the dependent variable consisted of variation between individuals, whereas $9.65 \%$ consisted of variation between countries (Table 3, Model 0). All individual-level variables were statistically significantly associated with self-rated health (Table 3, Model 1a). Male gender, years in full-time education, paid work during the last seven days as opposed to main activity being housework or other, and being married or in a civil partnership, as opposed to having never been married or in a civil partnership, increased the chances to have good or very good health. The reduction in unexplained between-country variance (-5.7) in health changed only slightly when the individual-level variables were incorporated into the empty model.

When each of the country-level cultural variables was included one at a time in the model already including the individual-level sociodemographic variables, the following six variables were statistically significantly and positively associated with the dependent variable: the percentage of arts students $(\mathrm{p}=.010)$, the RC index ( $\mathrm{p}=.001)$, the percentage of writers and creative artists of total employment ( $\mathrm{p}=.038)$, exports of cultural goods $(\mathrm{p}=.005)$, imports of cultural goods $(\mathrm{p}<.001)$, and the number of feature films produced per capita ( $p=.039$ ) (Table 3, Models 2a-2f). E.g., a one percent increase in the number of tertiary arts students of all students signified an increase of $20 \%$ in the odds of having good or very good health. The inclusion of these variables in the model only modestly accounted for the country differences; based on intra-class correlations, from $4.12 \%$ to $7.61 \%$ of the variation was explained by various cultural variables. The variable indicating imports of cultural goods had slightly more explanatory power than that of the other variables. The inclusion of that variable into the model decreased unexplained between-country variance by $60.0 \%$. Also the RC index decreased the variance to a remarkable degree, by $40.0 \%$.

--- Table 3. here ---

Individual-level trust was then added to each one of the Models 2a-2f. The following cultural variables remained statistically significant: the percentage of arts students $(p=.011)$, the $R C$ index $(p=.002)$, exports of 
cultural goods ( $\mathrm{p}=.004)$, and imports of cultural goods $(\mathrm{p}<.001)$. After the incorporation of the GDP variable into each model already including the individual-level variables (also trust) and one of these four cultural variables, only the variable indicating imports of cultural goods remained statistically significant. The same applied to the welfare state regime variable. Gini coefficient in the models didn't have that effect, but each one of the cultural variables remained statistically significant.

When trust measured on country level was added to the Models 2a-2f, only exports ( $p=.007)$ and imports of cultural goods ( $\mathrm{p}<.001$ ) were statistically significantly associated with self-rated health. However, the statistical significance of the exports variable vanished, when either GDP or welfare state regime were incorporated into the model in addition to trust. The Gini index didn't have that consequence. None of these country-level control variables had an impact on the statistically significant association between imports of cultural goods and self-rated health.

Among the cultural indicators, the number of UNESCO world heritage sights, the number of capitals of culture, and cultural employment were not statistically significantly associated with self-rated health in any analysis. The indicator describing harmonized indices of consumer prices for main cultural goods and services in the countries had a borderline level of statistical significance with self-rated health (OR=.98; 95\% CI: .954, 1.00; $\mathrm{p}=.050)$.

\section{Discussion}

The starting point for this research was the notion that country-level investment in opportunities for cultural and artistic activities - the creation of a cultural opportunity structure - might be associated with the selfrated health of individuals. The associations then could be accounted for by social capital, measured as institutional trust, which is known to be related to various dimensions of health (see Rostila 2013). Behind cultural opportunity structures would be activities at the macro-level of the society (see Lowndes and Wilson 2001; Maloney et al. 2000) which form the groundwork for social capital by creating an infrastructure that enables people to act together and form networks (Maloney et al. 2000). Most of the variance (90.35\%) in self-rated health in our data was explained by individual level socioeconomic factors that were known to be crucial for the variation of both health and institutional trust (see Habibov and Afandi 2011; Kouvo 2011). Six cultural indicators were statistically significantly associated with self-rated health in a multilevel analysis, after controlling for the individual-level socioeconomic variables. These were the percentages of writers and creative artists out of total employment in 2009, arts students as a percentage of all students in 2007/2008, the total number of feature films produced per 100000 members of the population in 2006, European recreation and culture expenditure (RC) index in 2005, exports of cultural goods per population in 2002, and imports of cultural goods per member of the population in 2002. Thus, based on our selection of cultural indicators, some public investments had connections - although modest - with the health of 
individuals independently of socioeconomic positions. The indicator most strongly accounting for the health differences between the countries was the one indicating imports of cultural goods.

The other part of the hypothesis regarding institutional trust as a mediator between cultural opportunities and self-rated health was based on abundant but fragmented research activity pointing to social capital as one plausible connecting mechanism (e.g., Lindström and Mohseni 2008; Hyyppä and Mäki 2003). Institutional trust, whether measured at the individual or country level, played a role as a mediator between cultural indicators and health. Individual-level trust accounted for the association between the percentage of writers and creative artists and health and the association between the produced feature films and health. The role of country-level trust was even stronger; after the incorporation of it into the models, only exports and imports of cultural goods remained statistically significant. Furthermore, much of the association between health, cultural indicators and institutional trust could be traced back to the country's wealth, as indicated by GDP. In previous research, both economic factors and social capital have played roles in area differences with respect to self-rated health, where the role of economic factors is stronger (Carlson et al. 2004). It thus seems that the same countries augment both their prosperity and social capital, which together may increase the probability of good self-rated health among the citizens. This finding is consistent with Rostila (2013), a study based on an analysis of European welfare states. In the study, welfare state generosity was a decisive factor in the creation of social capital, which then had significance for health inequalities both between and within the welfare states (Rostila 2013).

Also in our data, the type of the organization of social welfare in European countries, as indicated by the welfare state regimes, mediated the association between cultural indicators and health but economic inequality within the countries (the Gini index) did not have this impact. It is, thus possible that cultural policies differ in countries pursuing different types of welfare policies (see Toepler, S., \& Zimmer 2002), to a degree which is relevant for trust and/or health. This is something which remains to be studied. The variable indicating imports of cultural goods was independently associated with health in spite of its strong correlation with GDP. This indicator may depict not only the economic value of cultural trade, but also its impact on society at large, including social meanings (van der Pol 2006). To better understand the operation of these macro-level factors, information about the way money is directed to support art and culture would have been useful, but it was not found in all of the countries in our data. A comparative analysis shows big differences in cultural expenditure per capita in European countries (Council of Europe 2009). These differences depend on the status of culture and the use of cultural services within countries, which are based on national cultural traditions and preferences in cultural policies. For example, the level of public funding of culture is clearly lower in Finland than in the other Nordic countries. (Ministry of Education 2009.) Considerable differences exist in government expenditure among European countries (Council of Europe 2016). This is interesting because of the relatively big health inequalities in Finland compared to other Nordic countries (OECD 2013). It is possible that investments in culture influence both the economies of the countries and other opportunity structures, which increase the health resources of individuals. 
One fundamental question related to the entire analysis is whether social capital at all - and institutional trust in particular - can be increased by adding to opportunities for cultural participation. According to Putnam (1993), social capital is largely determined by historical factors. However, some researchers believe in its shorter-term creation (Petersen 2002) and see it as a by-product of other activities (Uslaner and Dekker 2001; Alessandrini 2002; Falk and Harrison 1998). Nevertheless, social capital might be produced by the government, nongovernmental organizations or other actors in civil society (Cernea 1993; Huntoon 2001; Mondal 2000). The mechanisms creating institutional trust are vaguely known, and the interpretations of its dimensions in surveys may depend on regional, cultural, and individual differences (Schneider 2016; Shockley et al. 2016). It has been suggested that the analysis of these mechanisms should also include the variable indicating so-called generalized trust in other people (Abbott and Freeth 2008), which is also associated with self-rated health and other positive individual-level outcomes (Carl and Billari 2014). The experienced institutional trust, e.g., trust in the fairness of the societal institutions have been regarded as being closely intertwined with generalized attitudes about others (Rothstein and Stolle 2003). Including both of these indicators in the analysis would enable the separation of the components of trust and their relative impact on outcomes (e.g., Kouvo 2011). Recent studies in European countries suggest that individual and contextual trust may interact in complex and country-wise differing ways to influence self-rated health (Campos-Matos et al. 2015; Habibov and Afandi 2011). There was indication of this also in our data; the different mediating roles played by individual-level trust and country-level trust may depend either on their different meanings for people in the studied countries or on computational features of multilevel models, e.g., the number of level-2 units (Bryan and Jenkins 2015).

Places rich in cultural heritage or investments that should be valued might be regarded as indicators of the long-term creation of cultural infrastructure and "general cultural atmosphere" in a country. In our data, however, the number of UNESCO world heritage sights, the number of capitals of culture and cultural employment - in addition to the harmonized indices of consumer prices for main cultural goods and services - were not associated with health. The worldwide dispersion of the heritage sites has been found to depend on various historical, economic, and political factors in countries (Frey et al. 2013). It is also plausible that a simple compilation of statistics on these indicators does not catch the impact cultural heritage may have for individuals (see WHO 1989). The influences of tradition, history and aesthetic values might be more efficiently studied using other types of methodologies within the frameworks of visual culture (e.g., Haapala 2005), (cultural or heritage) tourism (e.g., McGehee et al. 2010; Murzyn-Kupisz 2012), or psychological research on cultural identity (see Eames 2007). The health impacts of activities that take place in the capitals of culture have been evaluated (e.g., Vahlo and Ruoppila 2013), and there are substantial differences in the funding and organization of activities and participation among the residents. In addition, the sustainability of the developed structures beyond the year as a capital of culture has been questioned (Rampton et al. 2012). Ways to evaluate the economic and quality of life impacts of cultural heritage have been developed as well (Fujiwara et al. 2014; Scanlon et al. 2014). The variable measuring cultural services, however, was very weakly correlated with all other variables. 
The need to find a selection of uniformly constructed cultural indicators that is as wide as possible and from as many countries as possible to enable multilevel analysis (see Bryan and Jenkins 2015) led us to selecting country as the macro-level unit instead of, e.g., region or administrative unit. There is no certain self-evident answer to the question about the context most appropriate for researching what cultural investments mean for health (see Macinko and Starfield 2001). The opportunity structures relevant for participation may in reality be found nearer to the individuals, at the regional or neighborhood level. Indeed, often only a small percentage of individuals' health has been attributed to the macro-level (e.g., Giordano et al. 2011; Fujisawa et al. 2009; Lindström et al. 2004; Poortinga 2006b; Snelgrove et al. 2009). In this study as well, individual-level socioeconomic variables explained most of the variation so that the percentage of total variation in health attributable to the country context varied between $4 \%$ and $8 \%$. As related to the unit of measurement, the use of ecological indicators, such as public spaces or the numbers of voluntary organizations per capita are suggested instead of aggregating information collected from individuals (Veenstra 2005; Poortinga 2006a). Altogether, what is learned from the weak associations in this study, is the importance of carefully selecting the level of the contexts for research (see Giordano et al. 2011; Oksanen et al. 2010; Suzuki et al. 2010). Hopefully, in the future, a rich selection of indicators will be available that indicate both macro-level (state or country), meso-level (region, society), and individual-level opportunities for cultural participation and experiences (e.g., Harpham et al. 2002; Jen et al. 2010). These indicators should be based on shared understanding of what is meant by artistic and cultural participation (see Davies et al. 2012).

Related to the variation in health, is also the more or less equal division of cultural opportunities within a society. Membership in groups having cultural resources and interest in participation may be firmly rooted - even in people's early years - in different population groups (Bourdieu 1986), which means that the publicly funded cultural supply is mostly enjoyed by those able to read the appropriate codes and find activities promoting trust, health and well-being. Cultural opportunity structures might create mostly bonding social capital among homogeneous population groups, as opposed to bridging social capital, which brings people who come from different backgrounds closer to one another (see Putnam 2000). Hence, cultural participation might even widen inequality, either not allowing “outsiders” admittance into beneficial networks or making them feel that the cultural distance is too far (see. Campos-Matos et al. 2015; Rostila 2013). In this study, account was taken of individual-level socioeconomic factors, but it nonetheless remains to be studied whether country-level investments in culture might add to the social capital of all or only benefit some population groups that are already privileged and equipped with capacities for social participation. In several countries, Finland included, new forms of collaboration between sectors of society have been undertaken to add to everybody's right to participate in the cultural life of the community for their health and well-being (Liikanen 2010; Parkinson and White 2013).

Further, it is possible that cultural investments and "cultural atmosphere" might indeed influence health through other mechanisms - such as the learning of new skills and the adoption of an aesthetic outlook on life during participation in cultural activities - that may have an impact on health through the 
creation of intellectual or human capital (see OECD 2010). Education in the arts and cultural fields might be better measured using indicators of human capital as opposed to social capital. Additionally, cultural capital (and not social capital), which includes cultural inheritance, myths, shared values, ideologies and rituals as its elements, might become a useful concept when conducting research on the link between cultural and artistic participation and health (see Eames 2007). Cultural capital could also be understood in the Bourdieuian framework (Bourdieu 1986) emphasizing the diversity of cultural preferences and tastes among population groups (e.g. Kim and Kim 2009). This could help in directing investments in cultural opportunity structures in ways which have potential for leveling off health inequality caused by unevenly distributed social, cultural and economic resources (see Veenstra and Abel 2015).

To my knowledge, no comparable analysis based on cultural indicators has been performed to offer points of reference to assess the findings of this study. The indicators used here reflect a wide range of investments in cultural and artistic activities, from which citizens can profit directly and indirectly, e.g., through education of future professionals. The high mutual correlations of the most important indicators and their correlations with certain other indicators further emphasize the probability that, if there are investments in one field of culture, there are likely investments in other fields as well. Our indicators may be regarded as a miscellaneous collection of both simple one-item measures and measures constructed from various ingredients because we used every indicator available from as many countries as possible which were collected by a reasonable effort. This may be regarded as a source of variation in the validity of indicators. E.g., feature films include all full-length films intended to be commercially shown in cinemas, be they fictional, animated or documentary (UNESCO Institute for Statistics 2012). “Art films” are seldom seen in the lists presenting the Top 20 most popular feature films (UNESCO Institute for Statistics 2013). However, European film production has been regarded as promoting the diversity of cultural expressions (UNESCO Instítute for Statistics 2014). Basing the indicators on the work performed systematically by UNESCO and Eurostat and their definitions of culture (e.g., UNESCO Institute for Statistics 2001) contributes to the development of a theoretical basis that can be further developed. The work performed that aimed at the production of cultural statistics has progressed (Council of Europe 2015) and will lead to more comprehensive research designs, including data on actualized participation. In future research, data available on the various ways to use the Internet and social media in the creation of social capital (e.g., Neves and Fonseca 2015; Sajuria et al. 2014) might be used. Altogether, indicators available for population level research should be based on a comprehensive, and evidence-based, theoretical framework in which both the general processes linking cultural and artistic activity with health and more specific processes, involving particular forms of cultural activities and particular dimensions of health, could be analyzed (see Clift et al. 2009; Clift 2012). There seems to be a great variability among paths from various forms of artistic behavior to health and well-being depending on e.g. the frequency of the activities and the total time used for them. There is also a need for more profound contemplation of the values connected with those activities by individuals and societies, e.g., whether they are regarded as intrinsic or instrumental. (Michalos and Kahlke 2008; Parkinson and White 2013.) 
The comparison of countries may have been influenced by differences in the assessments of self-rated health, both between (Jürgens 2008) and within countries between population groups (Van Doorslaer and Gerdtham 2003). However, the five-category question about self-rated health has been regarded as a good predictor of objective health status (Poortinga 2006a) and also fairly insensitive to differences in wording, making it relevant in comparative cross-country studies (Idler and Benyamini 1997). We did not compare the proportions of total variation in health explained at the community level. The power to detect these variance components might have been too small with our 21 countries (see Snijders and Busker 1999). The next stage of analysis might have been to search for similarities and differences between countries, such as those representing different welfare state regimes (e.g., Brennenstuhl et al. 2012) or stages of economic development. In some transitional countries, an analysis by Habibov and Afandi (2011) helped illuminate whether individual level factors and social capital influenced health independently of one another or whether social capital collectively benefited people in various countries beyond the individual level factors. Their analysis succeeded in showing whether it would be better to influence individual-level factors or countrylevel factors to create social capital (Habibov and Afandi 2011). These types of possibilities should be borne in mind when interpreting the results of these data.

With a cross-sectional design, inferences regarding causal mechanisms cannot be made. As Habibov and Afandi (2011) indicate, it is possible that poor health leads to lower social capital or that people with poorer health tend to report lower levels of institutional trust. It is also possible that a selection process takes place such that individuals with high trust choose to live in communities with higher levels of trust. There is some evidence showing that the negative impact of economic inequality on social trust and, consequently, on health may vary during the life course (Rözer and Volker 2916). This may apply to institutional trust as well. These types of causal processes could not be addressed in this study. A fruitful area of research could be one concentrating on studying the roles of the individual, the state, and the market in the cultural policies representing different welfare state regimes and how the changes in the organization of social welfare have influenced the cultural opportunity structures in the long run (see Toepler and Zimmer 2002).

Altogether, our research showed that over and above individual-level socioeconomic factors, certain variables indicating the country's investment in opportunities for participation in cultural activities among the citizens were associated - even if moderately - with self-rated health. Thus, cultural policies practiced in European countries may form channels through which the health of individuals could be influenced and health equity could be promoted. What must be remembered, is that there are differences in individual abilities to make use of the fruits of cultural policies; special emphasis should be put on those, whose physical or psychosocial health status forms an obstacle for participation, thus creating inequality already in the first place. There was some indication that the associations might be mediated by institutional trust, which is regarded as a form of social capital. However, cultural opportunities and institutional trust seemed to be both intertwined and also concomitants of the country's general prosperity. More refined research is required based on measuring both cultural participation and the generation of trust on not only the individual and macro-levels, but also on the meso-level, e.g., in municipalities and societies. 


\section{Conflict of interest}

None declared. 


\section{References}

Abbott, S., \& Freeth, D. (2008). Social capital and health. Journal of Health Psychology 13(7), 874-883.

Ahlquist, J., Lindström, M., \& Wamala, S. P. (2008). Institutional trust and alcohol consumption in Sweden: The Swedish National Public health Survey. BMC Public Health 8, 283. doi:10.1186/1471-2458-8-283

Aittomäki, A., Martikainen, P., Laaksonen, M., Lahelma, E., \& Rahkonen O. (2010). The associations of household wealth and income with self-rated health - A study on economic advantage in middle-aged Finnish men and women. Social Science \& Medicine 71(5), 1018-1026.

Alessandrini, M. (2002). Is civil society an adequate theory? Third Sector Review 8(2), 105-119.

Balandin, S. (2011). Participation by adults with lifelong disability: more than a trip to the bowling alley. International Journal of Speech-Language Pathology 13(3), 207-217. doi: 10.3109/17549507.2011.549569.

Bartley, M. (2004). Health inequality. An introduction to theories, concepts and methods. Cambridge: Polity Press.

Bolin, K., Lindgren, B., Lindstrom, M., \& Nystedt, P. (2003). Investments in social capital implications of social interactions for the production of health. Social Science \& Medicine 56(12), 2379-2390.

Bourdieu, P. (1984). Distinction: A social critique of the judgment of taste. Cambridge, MA: Harvard University Press.

Bourdieu, P. (1986). The forms of capital. In J. G. Richardson (Ed.), Handbook of theory and research for the sociology of education (pp. 117-142). Connecticut: Greenwood Press.

Bowles, S., \& Gintis, H. (2002). Social capital and community governance. The Economic Journal, 112(483), 419-436.

Bowling, A., \& Zahava, G. (2004). An international model of quality of life in older age, results from the ESRC/MRC HSRC quality of life survey in Britain. Social Indicators Research 69(1), 1-36.

Von Brandenburg, C. (2008). Kulttuurin ja hyvinvoinnin välisistä yhteyksistä. Näköaloja taiteen soveltavaan käyttöön. Ministry of Education 2008: 12.

http://www.minedu.fi/export/sites/default/OPM/Julkaisut/2008/liitteet/opm12.pdf?lang=fi . Accessed 22 June 2015.

Brennenstuhl, S., Quesnel-Vallée, A., \& McDonough, P. (2012). Welfare regimes, population health and health inequalities: a research synthesis. Journal of Epidemiology and Community Health 66(5), 397409.

Bryan, M. L., \& Jenkins, S. P. (2015). Multilevel modelling of country effects: a cautionary tale. European Sociological Review. doi: 10.1093/esr/jcv059

Bygren, L. O., Johansson, S. E., Konlaan, B. B., Grjibovski, A, M. Wilkinson, A. V, \& Sjöström, M. (2009b). Attending cultural events and cancer mortality: a Swedish cohort study. Arts \& Health 1(1), 64-73.

Bygren, L. O., Weissglas, G., Wikström, B., Konlaan, B. B., Grjibovski, A., Karlsson, A. B., et al. (2009a). Cultural participation and health: a randomized controlled trial among medical care staff. Psychosomatic Medicine 71(4), 469-473.

Campos-Matos, I., Subramanian, S. V., \& Kawachi, I. (2015). The 'dark side' of social capital: trust and selfrated health in European countries. European Journal of Public Health. doi: http://dx.doi.org/10.1093/eurpub/ckv089

Carl, N., \& Billari, F. C. (2014). Generalized trust and intelligence in the United States. Plos ONE 9(3), e91786. doi: 10.1371/journal.pone.0091786.

Carlson, P. (2004). The European health divide: a matter of financial or social capital? Social Science \& Medicine 59(9), 1985-1992.

Cernea, M. M. (1993). The sociologist’s approach to sustainable development. Finance Development 30(4), 11-15.

Chan, T. W., \& Goldthorpe, J. H. (2010). Social status and cultural consumption. In T. W. Chan \& J. H. Goldthorpe (Eds.), Social status and cultural consumption (pp. 1-27). Cambridge: University Press, Cambridge.

Clift S. (2012). Creative arts as a public health resource: moving from practice-based research to evidencebased practice. Perspectives in Public Health 132(3), 120-127. 
Clift, S., Camic, P. M., Chapman, B., Clayton, G., Daykin, N., Eades, G., et al. (2009).The state of arts and health in England. Arts \& Health (1(1), 6-35.

Clift, S. M., \& Hancox, G. (2010). The significance of choral singing for sustaining psychological wellbeing: findings from a survey of choristers in England, Australia and Germany. Music Performance Research 3(1), 79-96.

Cohen, G. (2009). New theories and research findings on the positive influence of music and art on health with ageing. Arts \& Health 1(1), 48-63.

Cohen, G. D., Perlstein, S., Chapline, J., Kelly, J., Firth, K. M., \& Simmens, S. (2006). The impact of professionally conducted cultural programs on the physical health, mental health, and social functioning of older adults. The Gerontologist 46(6), 726-734.

Coleman, J. (1988). Social capital in the creation of human capital. American Journal of Sociology, 94 (Suppl.) 95-120.

Council of Europe/ERICarts, (2011). Compendium of cultural policies and trends in Europe, $12^{\text {th }}$ edition. http://www.culturalpolicies.net/. Accessed 20 November 2012.

Council of Europe/ERICarts (2015). Compendium of Cultural Policies and Trends in Europe, 16th edition, 2015. http://www.culturalpolicies.net/web/statistics-resources.ohp.Accessed 23 June 2015.

Council of Europe/ERICarts (2016). Compendium of Cultural Policies and Trends in Europe, 16th edition, 2016. www.culturalpolicies.net/web/countries-quick-facts.php?pcid=1490. Accessed 5 August 2016.

Council of Europe (2009). Compendium of cultural policies and trends in Europe, 10th edition (2009) and www.culturalpolicies.net (Great Britain), Eurostat, IMF World Economic Outlook Database.

Cuypers, K., Krokstad, S., Holmen, T. L., Knudtsen, M. S., Bygren, L. O., \& Holmen, J. (2012). Patterns of receptive and creative cultural activities and their association with perceived health, anxiety, depression and satisfaction with life among adults: the HUNT study, Norway. Journal of Epidemiology and Community Health 66, 698-703.

Dahl, E., \& Malmberg-Heimonen, I. (2010). Social inequality and health: the role of social capital. Sociology of Health and Illness 32(7), 1102-1119.

Davies, C. R., Rosenberg, M., Knuiman, M., Ferguson, R., Pikora, T., \& Slatter, N. (2012). Defining arts engagement for population-based health research: art forms, activities and level of engagement. Arts \& Health 4(3), 203-216.

Eames, P. (2007). Cultural well-being and cultural capital. Waikanae, New Zealand: CSE Consultancy. http://www.parliament.nz/resource/en-

nz/49SCGA_EVI_00DBHOH_BILL10036_1_A140442/d6d97878ae81fd660f2e1cdfe014b94fa8c0be48 . Accessed 22 June 2015.

Edwards, B., \& Foley, M. (1998). Civil society and social capital beyond Putnam. American Behavioural Scientist 42(1),124-132.

Eikemo, T.A., Bambra, C., Judge, K., \& Ringdal, K. (2008). Welfare state regimes and differences in self-perceived health in Europe: a multilevel analysis. Social Science \& Medicine 66 (11), 2281-2295.

Eriksson, I., Undén, A. L., \& Elofsson, S. (2000). Self-rated health. Comparisons between three different measures. Results from a population study. International Journal of Epidemiology 30(2), 326-333.

Espig-Andersen, G. (1990). The three worlds of welfare capitalism. New Jersey: Princeton University Press.

European Social Survey (2008): ESS-3 2006 Documentation report. Edition 3.2. Bergen: European Social Survey Data Archive, Norwegian Social Science Data Services.

Eurostat (2007). Cultural statistics. Eurostat pocketbooks. http://ec.europa.eu/eurostat. Accessed 24 May 2009.

Eurostat (2011). Eurostat newsrelease 55/2011 - 14 April 2011. Culture in the EU27. Cultural statistics in the spotlight. http://epp.eurostat.ec.europa.eu/cache/ITY_PUBLIC/3-14042011-AP/EN/3-14042011AP-EN.PDF. Accessed 23 June 2015.

Eurostat (2015). Gini coefficient of equivalised disposable income (source: SILC). http://ec.europa.eu/eurostat/tgm/table.do?tab=table\&language=en\&pcode=tessi190. Accessed 11 February 2015.

Falk, I, \& Harrison, L. (1998). Community learning and social capital: 'Just having a little chat'. Journal of Vocational Education and Training 50(4), 609-627.

Ferrera, M. (1996). The southern model of welfare in social Europe. Journal of European Social Policy 6(1), $17-37$. 
Franzini, L., Caughy, M., Spears, W., \& Fernandez Esquer, M. E. (2005). Neighborhood economic conditions, social processes, and self-rated health in low-income neighborhoods in Texas: a multilevel latent variables model. Social Science \& Medicine_61(6), 1135-1150.

Freitag, M. (2003). Social capital in (dis)similar democracies. The development of generalized trust in Japan and Switzerland. Comparative Social Studies 6(8), 936-966.

Frey, B. S., Pamini, P., \& Steiner, L. (2013). Explaining the world heritage list: an empirical study. International Review of Economics. doi 10.1007/s12232-013-0174-4.

Fritzell, J., Nermo, M., \& Lundberg, O. (2004). The impact of income: assessing the relationship between income and health in Sweden. Scandinavian Journal of Public Health 32(1), 6-16.

Fujisawa, Y., Hamano, T., \& Takegawa, S. (2009). Social capital and perceived health in Japan: an ecological and multilevel analysis. Social Science \& Medicine 69(4), 500-505.

Fujiwara, D., Cornwall, T., \& Dolan, P. (2014). Heritage and wellbeing. London: English Heritage. http://hc.historicengland.org.uk/content/pub/2190644/heritage-and-wellbeing.pdf. Accessed 23 February 2016.

Fukuyama, F. (2002). Social capital and development: the coming agenda. SAIS Review 22(1), $23-37$.

Giordano, G., \& Lindström, M. (2010). The impact of changes in different aspects of social capital and material conditions on self-rated health over time: a longitudinal cohort study Social Science \& Medicine 70(5), 700-710.

Giordano, G. N., Ohlsson, H., \& Lindström, M. (2011). Social capital and health-purely a question of context? Health \& Place 17(4), 946-953.

Haapala, A. (2005). On the aesthetics of the everyday - familarity, strangeness and the meaning of place. In A. Light \& J. Smith (Eds.), The aesthetics of everyday life (pp. 39-55). New York: Columbia Univesity Press.

Habibov, N. N., \& Afandi, E. N. (2011). Self-rated health and social capital in transitional countries: multilevel analysis of comparative surveys in Armenia, Azerbaijan, and Georgia. Social Science \& Medicine 72(7), 1193-1204.

Harpham, T., Grant, E., \& Thomas, E. (2002). Measuring social capital within health surveys: key issues. Health Policy and Planning 17(1), 106-111.

Harteveld, E., van den Meer, T., \& De Vries, C. E. (2013). In Europe we trust? Exploring three logics of trust in the European Union. European Union Politics 14(4), 542-565.

Heller, P. (1996). Social capital as a product of class mobilization and state intervention: industrial workers in Kerala, India. World Development 24(6), 1055-1071.

Helliwell, J. F., \& Putnam, R. D. (2004).The social context of well-being. Philosophical transactions of the Royal Society of London. Series B, Biological Sciences. 359(1449), 1435-1446.

Hinkle, D. E., Wiersma, W, \& Jurs, S. G. (2003). Applied Statistics for the Behavioral Sciences. Boston: Houghton Mifflin.

d’Hombres, B., Rocco, L., Suhrcke, M., \& McKee, M. (2010). Does social capital determine health? Evidence from eight transition countries. Health Economics 19(1), 56-74.

Hough, M., Jackson, J., Bradford, B. Myhill, A, \& Quinton, P. (2010). Procedural justice, trust, and Institutional legitimacy. Policing 4(3), 203-210.

Hox, J. (2002). Multilevel analysis: Techniques and applications. Mahwah, New Jersey: Lawrence Erlbaum Associates, Inc.

Huntoon, L. (2001). Government use of nonprofits to build social capital. Journal of Socio-Economics 30(2), 157-160.

Hyyppä, M. T., \& Mäki, J. (2003). Social participation and health in a community rich in stock of social capital. Health Education Research 18(6), 770-779.

Hyyppä, M. T., \& Mäki, J. (2001). Why do Swedish-speaking Finns have longer active life? An area for social capital research. Health Promotion International 16(1), 55-64.

Hyyppä, M. T., Mäki, J., Impivaara, O., \& Aromaa, A. (2006). Leisure time participation predicts survival: a population-based study in Finland. Health Promotion International 21(1), 5-11.

Idler, E. L., \& Benyamini, Y. (1997). Self-rated health and mortality: a review of twenty-seven community studies. Journal of Health and Social Behavior 38(1), 21-37. 
Idler, E. L., Russell, L. B., \& Davis, D. (2000). Survival, functional limitations, and self-rated health in the NHANES I epidemiologic follow-up study. First National Health and Nutrition Examination Survey. American Journal of Epidemiology 152(9), 874-883.

Inglehart, R. (1997). Modernization and postmodernization: cultural, economic, and political change in 43 Societies. Princeton: Princeton University Press.

Islam, M., Merlo, J., Kawachi, I., Lindström, M., \& Gerdtham, U. (2006). Social capital and health: does egalitarianism matter? A literature review. International Journal for Equity in Health 5(3). doi:10.1186/1475-9276-5-3

Janowski, K., Steuden, S., \& Kuryłowicz, J. (2010). Factors accounting for psychosocial functioning in patients with low back pain. European Spine Journal 19(4), 613-623. doi:10.1007/s00586-009-1151-1

Jen, M. H., Sund, E. R., Johnston, R., \& Jones, K. (2010). Trustful societies, trustful individuals, and health: An analysis of self-rated health and social trust using the World Value Survey. Health and Place 16(5), 1022-1029.

Jensen, A. (2013). Beyond the borders: the use of art participation for the promotion of health and wellbeing. Arts \& Health 5(3), 204-215.

Joutsenniemi, K. E., Martelin, T. P., Koskinen, S. V., Martikainen, P. T., Härkänen, T. T., Luoto, R. M. et al. (2006). Official marital status, cohabiting, and self-rated health-time trends in Finland, 1978-2001. European Journal of Public Health 16(5), 476-83.

Jürges, H., Avendano, M., \& Mackenbach, J. P. (2008). Are different measures of self-rated health comparable? An assessment in five European countries. European Journal of Epidemiology 23(12), 773-781.

Kawachi, I., Berkman, L., (2000). Social cohesion, social capital, and health. In L. Berkman \& I Kawachi (Eds.), Social epidemiology (pp. 174-190). New York: Oxford university press, Inc.

Kawachi, I., Kennedy, B. P., \& Glass, R. (1999). Social capital and self-rated health: a contextual analysis. American Journal of Public Health 89(8), 1187-1193.

Khawaja, M., \& Mowafi, M. (2007). Types of cultural capital and self-rated health among disadvantaged women in outer Beisut, Lebanon. Scandinavian Journal of Public Health 35(5), 475-480.

Kilroy, A., Garner, C., Parkinson, C., Kagan, C., Senior, P. (2007). Towards transformation: exploring the impact of culture, creativity and the arts on health and wellbeing. Manchester Metropolitan University: Arts for Health, MMU..

Kim, D., Subramanian, S. V., \& Kawachi, I. (2006). Bonding versus bridging social capital and their associations with self-rated health: a multilevel analysis of 40 US communities. Journal of Epidemiology and Community Health 60(2), 116-122.

Kim, D., Baum, C. F. Baum, Ganz, M. L. Subramanian, S. V., \& Kawachi, I. (2011).The contextual effects of social capital on health: a cross-national instrumental variable analysis. Social Science \& Medicine 73(12), 1689-1697.

Kim, S. \& Kim, H. (2009). Does cultural capital matter?: cultural divide and quality of life. Social Indicators Research 93(2), 295-313.

Konlaan, B. B. (2001). Cultural experience and health. The coherence of health and leisure time activities. Umeå University Medical Dissertations, New Series No. 706.

Konlaan, B. B., Bygren, L. O., \& Johansson, S. E. (2000). Visiting the cinema, concerts, museums or art exhibitions as determinant of survival: a Swedish fourteen-year cohort follow-up. Scandinavian Journal of Public Health 28(3)174-178.

Kouvo, A. (2011). The sources of generalized trust and institutional confidence in Europe. Research on Finnish Society 4, 29-40.

Kröger, H., Pakpahan, E., \& Hoffman, R. (2015). What causes health inequality? A systematic review on the relative importance of social causation and health selection. The European Journal of Public Health Advance Access 1-10. doi:10.1093/eurpub/ckv111.

Latalova, K., Ociskova, M., Prasko, J., Kamaradova, D., Jelenova, D., \& Sedlackova, Z. (2013). Selfstigmatization in patients with bipolar disorder. Neuroendocrinology Letters 34(4), 265-272

Liikanen, H. L. (2010). Art and culture for well-being: proposal for an action programme 2010-2014. Helsinki: Ministry of Education and Culture.

Lin, N. (2001). Building a network theory of social capital. In N. Lin, K. Cook, \& R. S. Burt (Eds.), Social capital: Theory and research (pp. 3-29). Aldine de Gruyter: New York.

Lindstrom, M., \& Mohseni, M. (2008). Social capital, political trust and self-reported psychological health: 
A population-based study. Social Science \& Medicine 68(3), 436-443.

doi:10.1016/j.socscimed.2008.11.004

Lindström, M., Moghaddassi, M., \& Merlo, J. (2004). Individual self-reported health, social participation and neighbourhood: a multilevel analysis in Malmö, Sweden. Preventive Medicine 39(1), 135-141.

Link, B. G., Phelan, J. C., Miech, R., \& Westin, E. L. (2008). The resources that matter: fundamental social causes of health disparities and the challenge of intelligence. Journal of Health Social Behavior 49(4), 72-91.

Lopez, R. (2004). Income inequality and self-rated health in US metropolitan areas: a multi-level analysis. Social Science \& Medicine 59(12), 2409-2419.

Lowndes, V., \& Wilson, D. (2001). Social capital and local governance: exploring the institutional design variable. Political Studies 49(4), 624-647.

Macinko, J., \& Starfield, B. (2001). The utility of social capital in research on health determinants. The Milbank Quarterly 79(3), 387-427.

Mackenbach, J. P., Karanikolos, M., \& McKee, M. (2013). Health in Europe 1. The unequal health of Europeans: successes and failures of policies. The Lancet 381, 1125-1134.

Maloney, W., Smith, G., \& Stoker, G. (2000). Social capital and urban governance: adding a more contextualised 'top-down' perspective. Political Studies 48(4), 802-820.

Manor, O., Matthews, S., \& Power, C. (2000). Dichotomous or categorical response? Analysing selfrated health and lifetime social class. International Journal of Epidemiology 29(1), 149-157.

McGehee, N. G., Lee, S., O’Bannon, T. L., \& Perdue, R. R. (2010). Tourism-related social capital and its relationship with other forms of capital: an exploratory study. Journal of Travel Research 49(4), 486500.

Merlo, J., Ohlsson, H., Lynch, K. F., Chaix, B., \& Subramanian, S. V. (2009). Individual and collective bodies: using measures of variance and association in con textual epidemiology. Journal of Epidemiology and Community Health 63(12), 1043-1048.

Michalos, A. C., \& Kahlke, P. M. (2008). Impact of arts-related activities on the perceived quality of life. Social Indicators Research 89, 193-258. DOI 10.1007/s11205-007-9236-x.

Miilunpalo, S., Vuori, I., Oja, P., Pasanen, M., \& Urponen, H. (1997). Self-rated health status as a health measure: the predictive value of self-reported health status on the use of physician services and on mortality in the working-age population. Journal of Clinical Epidemiology 50(5), 517-528.

Miech, R. A., \& Hauser, R. M. (2001). Socioeconomic status and health at midlife: a comparison of educational attainment with occupation-based indicators. Annals of Epidemiology 11(2), 75-84.

Mills, D., \& Brown, P. (2004). Art and wellbeing. A guide to the connections between Community Cultural Development and Health, ecologically sustainable development, public housing and place, rural revitalisation, community strengthening, active citizenship, social inclusion and cultural diversity. Sydney: Australian Council for Arts.

Ministry of Education (2010). Finnish culture in European comparison. Ministry of Education Policy Analyses 2010:1.

http://www.minedu.fi/export/sites/default/OPM/Julkaisut/2010/liitteet/pol0110.pdf?lang=fi. Accessed 1 March 2016.

Mmari, K., Marshall, B., Lantos, H., \& Blum, R. W. (2016). Who adolescents trust may influence their health: findings from Baltimore. Journal of Urban Health 93(3):468-78. doi: 10.1007/s11524-0160038-9.

Mohseni, M., \& Lindstrom, M. (2007). Social capital, trust in the health-care system and self-rated health: the role of access to health care in a population-based study. Social Science \& Medicine 64(7), 13731383.

Mondal, A. H. (2000). Social capital formation: the role of NGO rural development programs in Bangladesh. Policy Sciences 33, 459-475.

Murzyn-Kupisz, M. (2012). Cultural, economic and social sustainability of heritage tourism: issues and challenges. Economic and Environmental Studies 12(2), 113-133.

Neves, B. B., \& Fonseca, J. R. (2015). Latent Class Models in action: bridging social capital \& Internet usage. Social Science Research 50, 15-30. doi: 10.1016/j.ssresearch.2014.11.002. 
Nenonen, T., Kaikkonen, R., Murto, J., \& Luoma, A. L. (2014). Cultural services and activities: the association with self-rated health and quality of life. Arts \& Health 6(3), 235-253.

Nieminen, T., Martelin, T., Koskinen, S., Aro, H., Alanen, E., \& Hyyppä, M. T. (2010). Social capital as a determinant of self-rated health and psychological well-being. International Journal of Public Health 55(6), 531-542.

Nieminen, T., Prättälä, R., Martelin, T., Härkänen, T., Hyyppä, M. T., Alanen, E., et al. (2013). Social capital, health behaviours and health: a population-based associational study. BMC Public Health 27(13), 613. doi:10.1186/1471-2458-13-613.

Nummela, O., Sulander ,T., Rahkonen, O., Karisto, A., \& Uutela A. (2008b). Social participation, trust and self-rated health: a study among ageing people in urban, semi-urban and rural settings. Health \& Place 14(2), 243-253.

Nummela, O., Sulander, T., Rahkonen, O., \& Uutela, A. (2008a). Associations of self-rated health with different forms of leisure activities among ageing people. International Journal of Public Health 53(5), 227-235.

OECD (2013). “Perceived health status”, in Health at a Glance 2013. OECD Indicators. http://dx.doi.org/10.1787/health_glance-2013-13-en OECD (2010). Social capital, Human capital and Health: what is the evidence? IRDES - Centre for Educational Research and Innovation. http://www.oecd.org/edu/research/45760738.pdf. Accessed 16 June 2015.

Oksanen, T., Kouvonen, A., Vahtera, J., Virtanen, M., \& Kivimaki, M. (2010). Prospective study of workplace social capital and depression: are vertical and horizontal components equally important? Journal of Epidemiology and Community Health 64(8), 684-689.

Pampel, F. C. (2006). Socioeconomic distinction, cultural tastes, and cigarette smoking. Social Science Quarterly 87(1), 19-35.

Parkinson, C., \& White, M. (2013). Inequalities, the arts and public health: towards an international conversation. Arts \& Health 5(3), 177-189.

Petersen, D. M. (2002). The potential of social capital measures in the evaluation of comprehensive community-based health initiatives. The American Journal of Evaluation 23(1),55-64.

Pickett, K. E., Wilkinson, R. G. (2015). Income inequality and health: a causal review. Social Science \& Medicine 128, 316-326.

van der Pol, H. (2006). Key role of cultural and creative industries in the economy. OECD. http://www.oecd.org/site/worldforum06/38703999.pdf. Accessed 1 March 2016.

Poortinga, W. (2006b). Do health behaviors mediate the association between social capital and health? Preventive Medicine 43(6), 488-493.

Poortinga, W. (2006a). Social relations or social capital? Individual and community health effect of bonding social capital. Social Science \& Medicine 63(1), 255-270.

Portes, A. (1998). Social capital: its origins and applications in modern sociology. Annual Review of Sociology, 24, 1- 24.

Putnam, R. (2000). Bowling Alone: The Collapse and Revival of American Community. New York: Simon and Schuster.

Putnam, R. D. (1993). Making Democracy Work. Civic Tradition in Modern Italy. Princeton, NJ: Princeton University Press.

Rampton, J., Mozuraityte, N., Andersson, H., Reincke, E. (2012). Ex-post Evaluation of 2011 European Capitals of Culture. Final Report for the European Commission. DG Education and Culture. Ecorys UK Ltd. Ref. Ares(2012)1246004 - 22/10/2012.

http://ec.europa.eu/programmes/creativeeurope/actions/documents/ecoc/2011/evaluation_en.pdf. Accessed 10 June 2015.

Raudenbush, S. W., \& Bryk, A. S. (2002). Hierarchical linear models: Applications and data analysis methods. Newbury Park, CA; Sage.

Rothstein, B., \& Stolle, D. (2003). Social capital, impartiality and the welfare state: An institutional approach. In M. Hooghe \& D. Stolle (Eds.), Generating social capital. Civil society and institutions in comparative perspective (pp. 191-210). New York: Palgrave MacMillan.

Rostila, M. (2013). Social capital and health inequality in European welfare states. Basingstoke: Palgrave Macmillan. http://www.palgraveconnect.com/pc/doifinder/10.1057/9781137305664.0001. Accessed 22 June 2015. 
Rözer, J. J., \& Volker, B. (2016). Does income inequality have lasting effects on health and trust? Social Science \& Medicine 149, 37-45. doi: 10.1016/j.socscimed.2015.11.047.

Sajuria, J., vanHeerde-Hudson, J., Hudson, D., Dasandi, N., Theocharis, Y. (2014). Tweeting alone? An analysis of bridging and bonding social capital in online networks. American Politics Research. doi:10.1177/1532673X14557942

Scanlon, K., Bartlett, W., \& Whitehead, C. M. E. (2014). The wider benefits of investments in the cultural heritage in the western Balkans: a pilot study. Council of Europe. (In Press)

Schneider, I. (2016).Can we trust measures of political trust? Assessing measurement equivalence in diverse regime types. Social Indicators Research. doi: 10.1007/s11205-016-1400-8.

Schultz, J., O’Brien, A. M., \& Tadesse, B. (2008). Social capital and self-rated health: results from the US 2006 social capital survey of one community. Social Science \& Medicine 67(4), 606-617.

Shockley, E., Neal, T. M. S., Pytlikzillig, L. M., \& Bornstein, B. H. (2016). Interdisciplinary perspectives on trust: towards theoretical and methodological integration. Springer International Publishing. doi: 10.1007/978-3-319-22261-5.

Smith, E. M., Sakakibara, B. M., \& Miller, W. C. (2016). A review of factors influencing participation in social and community activities for wheelchair users. Disability and Rehabilitation: Assistive Technology 11(5), 361-374. doi: 10.3109/17483107.2014.989420.

Snelgrove, J., Pikhart, H., \& Stafford, M. (2009). A multilevel analysis of social capital and self-rated health: evidence from the British Household Panel Survey. Social Science \& Medicine 68(11), 1993-2001.

Snijders, T., \& Busker,R. (1999). Multilevel analysis: An introduction to basic and advanced multilevel modelling. London: Sage Publications.

Staricoff, R., (2004). Arts in health: a review of the medical literature. Research report 36. Arts Council of England. http://www.artscouncil.org.uk/media/uploads/documents/publications/phpc0eMaS.pdf. Accessed 7 October 2011.

Subramanian, S. V., Kim, D., \& Kawachi, I. (2002). Social trust and self-rated health in US communities: a multilevel analysis. Journal of Urban Health Bulletin of the New York Academy of Medicine 79(4), S21S34.

Suzuki, E., Fujiwara, T., Takao, S., Subramanian, S., Yamamoto, E., \& Kawachi, I. (2010). Multi-level, cross-sectional study of workplace social capital and smoking among Japanese employees. BMC Public Health 10, 489-498.

Särkämö, T., Tervaniemi, M., Laitinen, S., Forsblom, A., Soinila, S., Mikkonen, M., et al. (2008). Music listening enhances cognitive recovery and mood after middle cerebral artery stroke. Brain 131(3), 866876.

Sztompka, P. (1999). Trust: A Sociological Theory. Cambridge: Cambridge University Press.

Toepler, S., \& Zimmer, A. (2002). Subsidizing the arts. In D. Crane, Kawashima N., \& Kawasaki, K. (Eds.), Global culture: media, arts, policy, and globalization (pp. 29-48). New York: Routledge.

Tyler, T. R., Mentovich, A., \& Satyavada, S (2013). What motivates adherence to medical recommendations? The procedural justice approach to gaining deference in the medical arena. Regulation \& Governance 8(3), 350-370. doi: 10.1111/rego.12043.

United Nations (2004). Creative industries and development. United Nations Conference on Trade and Development. Distr. GENERAL TD(XI)/BP/ 13. http://www.unctad.org/en/docs/tdxibpd13_en.pdf. Accessed 4 June 2004.

UNESCO Institute for Statistics (2011). Culture and communication statistics in the Data Centre. http://stats.uis.unesco.org/unesco/TableViewer/tableView.aspx?ReportId=1391.Accessed 20 November 2011.

UNESCO Institute for Statistics (2013). Feature film diversity. UIS Fact Sheet. May 2013, No. 24. http://www.uis.unesco.org/culture/Documents/fs24-feature-film-diversity-en.pdf. Accessed 15 February 2016.

UNESCO Institute for Statistics (2012). From international blockbusters to national hits. Analysis of the 2010 UIS Survey on Feature Film Statistics. UIS Information Bulletin No. 8. http://www.uis.unesco.org/FactSheets/Documents/ib8-analysis-cinema-production-2012-en2.pdf. Accessed 15 February 2016.

UNESCO Institute for Statistics (2005). International flows of selected cultural goods and services, 19942003. Defining and capturing the flows of global cultural trade. http://www.uis.unesco.org/Library/Documents/culture05_en.pdf. Accessed 23 June 2015. 
UNESCO Institute for Statistics (2001). Measuring cultural participation. 2009 framework for cultural statistics. Handbook No. 2. http://www.uis.unesco.org/culture/Documents/fcs-handbook-2-culturalparticipation-en.pdf. Accessed 23 June 2015.

UNESCO Institute for Statistics (2009). The 2009 UNESCO Framework for Cultural Statistics (FCS). http://www.uis.unesco.org/culture/Documents/framework-cultural-statistics-culture-2009-en.pdf. Accessed 20 November 2011.

Uslaner, E. M., \& Dekker, P. (2001). The 'social' in social capital. In P. Dekker, \& E. M. Uslaner (Eds.), Social capital and participation in everyday life (pp. 176-188). London: Routledge.

Vahlo, J. \& Ruoppila, S. (Eds.) (2013). Turku 2011 - Tieteen kulttuuripääkaupunki / Turku 2011 - The capital of science and culture. Turku: Turku 2011 Foundation. http://www.utu.fi/fi/yksikot/hum/yksikot/hktl/tutkimus/ktt/Documents/Tieteen_kulttuurip\%C3\%A4\%C 3\%A4kaupunki_netti.pdf. Accessed 22 June 2015.

Van Doorslaer, E., \& Gerdtham, U. G. (2003). Does inequality in self-assessed health predict inequality in survical by income? Evidence from Swedish data. Social Science \& Medicine 57(9), 1621-1629.

Veenstra, G. (2005). Location, location, location: contextual and compositional health effects of social capital in British Columbia, Canada. Social Science \& Medicine 60(9), 2059-2071.

Veenstra, G., \& Abel. T. (2015). Capital interplays and the self-rated health of young men: results from a cross-sectional study in Switzerland. International Journal for Equity in Health 14(38). DOI 10.1186/s12939-015-0167-x

Verdonschot, M. M., de Witte, L. P., Reichrath, E., Buntinx, W. H., \& Curfs, L. M. (2009). Impact of environmental factors on community participation of persons with an intellectual disability: a systematic review. Journal of Intellectual Disability Research 53(1), 54-64. doi:10.1111/j.13652788.2008.01128.x.

Väänänen, A., Murray, M., Koskinen, A., Vahtera, J., Kouvonen, A., \& Kivimäki, M. (2009). Engagement on cultural activities and cause-specific mortality: prospective cohort study. Preventive Medicine 49(23), $142-114$.

WHO (1989). European charter on environment and health. WHO Regional Office for Europe. http://www.euro.who.int/en/health-topics/environment-and-health/pages/european-environment-andhealth-process-ehp/past-conferences-on-environment-and-health/first-ministerial-conference-onenvironment-and-health,-frankfurt-am-main,-1989/european-charter-on-environment-and-health. Accessed 23 June 2015.

Wilkinson, A. V., Waters, A. J., Bygren, L. O., \& Tarlov, A. R. (2007). Are variations in rates of attending cultural activities associated with population health in the United States? BMC Public Health 31(7), 226. doi:10.1186/1471-2458-7-226

Wilkinson, R. (2000). Inequality and the social environment: a reply to Lynch et al. Journal of epidemiology and Community health 54(6), 411-413.

Wilson, I. B., \& Kaplan, S. (1995). Clinical practise and patients' self-reported health status: how are the two related? Medical Care 33(4), S209-214.

Windsor, J. (2005). Your health and the arts: a study if the association between arts and engagement and health. London: Arts Council England. http://www.artscouncil.org.uk/media/uploads/documents/publications/yourhealth_phpfUVFl8.pdf. Accessed 7 October 2011.

Zoppei, S., Lasalvia, A., Bonetto, C., Van Bortel, T., Nyqvist, F., Webber, M. et al. (2014). Social Psychiatry and Psychiatric Epidemiology 49(10), 1589- 1598. doi:10.1007/s00127-014-0856-6. 
Table 1. Descriptive statistics of individual $(\mathrm{N}=24887)$ and country $(\mathrm{N}=21)$ level variables (ESS,Round 3, in 2006)

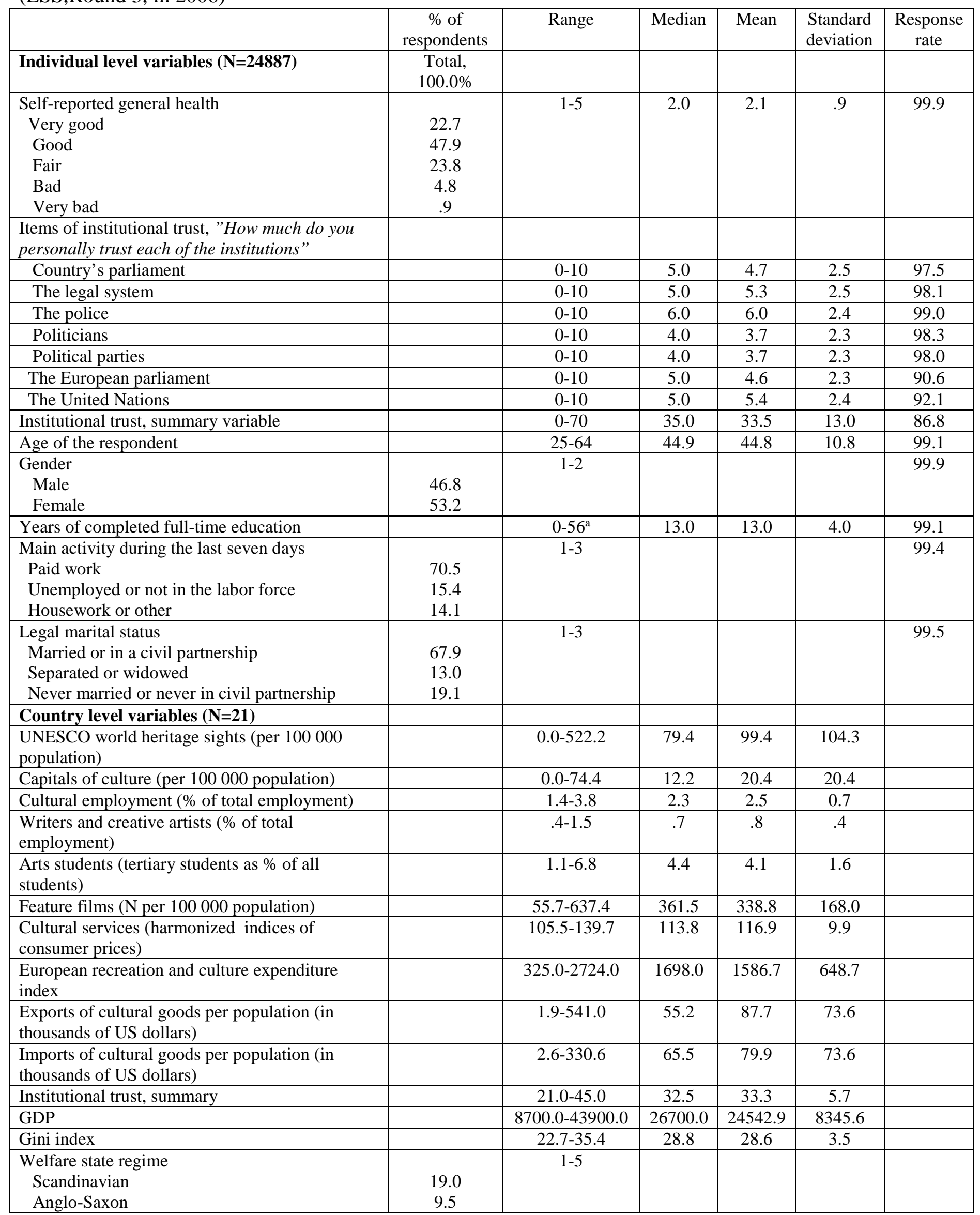




\begin{tabular}{|l|l|l|l|l|l|l|}
\hline Bismarckian & 28.6 & & & & & \\
Eastern-European & 28.6 & & & & & \\
Southern & 14.3 & & & & & \\
\hline
\end{tabular}

${ }^{\mathrm{a}} .3 \%$ of the respondents reported 25 or more years 
Table 2. Spearman correlation coefficients of the country-level explanatory variables $(\mathrm{N}=21)$

\begin{tabular}{|c|c|c|c|c|c|c|c|c|c|c|c|c|}
\hline Variable & $\begin{array}{c}\text { Capitals } \\
\text { of } \\
\text { culture } \\
\end{array}$ & $\begin{array}{c}\text { Cultural } \\
\text { employ- } \\
\text { ment } \\
\end{array}$ & $\begin{array}{c}\text { Writers } \\
\text { and } \\
\text { creative } \\
\text { artists }\end{array}$ & $\begin{array}{c}\text { Arts } \\
\text { students }\end{array}$ & $\begin{array}{c}\text { Feature } \\
\text { films }\end{array}$ & $\begin{array}{l}\text { Cultural } \\
\text { services }\end{array}$ & $\begin{array}{c}\text { RC } \\
\text { index } \\
\end{array}$ & $\begin{array}{c}\text { Exports of } \\
\text { cultural } \\
\text { goods } \\
\end{array}$ & $\begin{array}{c}\text { Imports of } \\
\text { cultural } \\
\text { goods } \\
\end{array}$ & Trust & GDP & $\begin{array}{c}\text { Gini } \\
\text { Index } \\
\end{array}$ \\
\hline $\begin{array}{l}\text { UNESCO } \\
\text { world heritage } \\
\text { sites }\end{array}$ & .173 & .029 & -.028 & .364 & .627 & .223 & .022 & -.227 & .040 & .360 & -.006 & .019 \\
\hline \multicolumn{2}{|c|}{ Capitals of culture } & .199 & .195 & .180 & .169 & .372 & -.007 & .114 & .092 & .217 & .229 & -.470 \\
\hline \multicolumn{3}{|c|}{ Cultural employment } & .693 & .406 & .251 & .193 & .575 & .513 & .431 & .625 & .559 & -.257 \\
\hline \multicolumn{4}{|c|}{ Writers and creative artists } & .167 & .157 & .085 & .740 & .652 & .596 & .673 & .767 & -.466 \\
\hline \multicolumn{5}{|c|}{ Arts students } & .388 & .060 & .377 & .389 & .539 & .336 & .416 & .308 \\
\hline \multicolumn{6}{|l|}{ Feature films } & .105 & .262 & .292 & .497 & .527 & .384 & .162 \\
\hline \multicolumn{7}{|l|}{ Cultural services } & -.071 & -.129 & -.156 & .030 & -.053 & -.137 \\
\hline \multicolumn{8}{|l|}{ RC index } & .694 & .806 & .642 & .840 & -.201 \\
\hline \multicolumn{9}{|c|}{ Exports of cultural goods } & .813 & .429 & .769 & -.242 \\
\hline \multicolumn{10}{|c|}{ Imports of cultural goods } & .656 & .913 & -.190 \\
\hline \multicolumn{11}{|c|}{ Trust } & .757 & -.392 \\
\hline \multicolumn{12}{|l|}{ GDP } & -.285 \\
\hline
\end{tabular}


Table 3. The multilevel models for subjective general health: the null model, the models for individual-level socio-demographic variables and statistically significant cultural indicators. Odds ratios (OR) and 95\% confidence intervals (95\% CI) $)^{\text {a }}$ for very good or good health and variance estimates

\begin{tabular}{|c|c|c|c|c|c|c|c|c|}
\hline Variable & $\begin{array}{l}\text { Model 0: } \\
\begin{array}{c}\text { Intercept } \\
\text { only }\end{array}\end{array}$ & $\begin{array}{l}\text { Model 1: Model } 0+ \\
\text { individual level socio- } \\
\text { demographics }\end{array}$ & $\begin{array}{l}\text { Model 2a: } 1+ \\
\text { Arts students } \\
\text { (country level) }\end{array}$ & $\begin{array}{c}\text { Model 2b: } 1 \\
\text { + RC index } \\
\text { (country } \\
\text { level) }\end{array}$ & $\begin{array}{l}\text { Model 2c: } 1+ \\
\text { Writers and } \\
\text { artists } \\
\text { (country } \\
\text { level) }\end{array}$ & $\begin{array}{l}\text { Model 2d: } 1+ \\
\text { Exports of } \\
\text { cultural goods } \\
\text { (country level) }\end{array}$ & $\begin{array}{l}\text { Model 2e: } 1+ \\
\text { Imports of } \\
\text { cultural goods } \\
\text { (country level) }\end{array}$ & $\begin{array}{c}\text { Model 2f: } 1 \\
\text { + Feature } \\
\text { films } \\
\text { (country } \\
\text { level) }\end{array}$ \\
\hline Individual-level & $\begin{array}{c}\text { OR } \\
(95 \% \mathrm{CI})\end{array}$ & $\begin{array}{c}\text { OR } \\
(95 \% \mathrm{CI})\end{array}$ & $\begin{array}{c}\text { OR } \\
(95 \% \mathrm{CI})\end{array}$ & $\begin{array}{c}\text { OR } \\
(95 \% \mathrm{CI})\end{array}$ & $\begin{array}{c}\text { OR } \\
(95 \% \mathrm{CI})\end{array}$ & $\begin{array}{c}\text { OR } \\
(95 \% \mathrm{CI})\end{array}$ & $\begin{array}{c}\text { OR } \\
(95 \% \mathrm{CI})\end{array}$ & $\begin{array}{c}\text { OR } \\
(95 \% \mathrm{CI})\end{array}$ \\
\hline Intercept & $\begin{array}{c}2.52 \\
(1.95-3.26)\end{array}$ & $3.91(2.85-5.35)$ & $1.881 .00-3.53)$ & $\begin{array}{l}1.64(.94- \\
2.88)\end{array}$ & $\begin{array}{l}2.29(1.27- \\
4.11)\end{array}$ & $3.10(2.23-4.30)$ & $2.421 .78-3.31)$ & $\begin{array}{l}2.39(1.37- \\
4.16)\end{array}$ \\
\hline Age & & $.96(.96-.97)$ & $.96(.96-.97)$ & $\begin{array}{l}.96(.96- \\
.97)\end{array}$ & $.96(.96-.97)$ & $.96(.96-.97)$ & $.96(.96-.97)$ & $.96(.96-.97)$ \\
\hline $\begin{array}{l}\text { Gender } \\
\text { Male } \\
\text { Female }\end{array}$ & & $\begin{array}{c}1.13(1.06-1.21) \\
1.00\end{array}$ & $\begin{array}{c}1.13(1.06-1.21) \\
1.00\end{array}$ & $\begin{array}{c}1.13(1.06- \\
1.21) \\
1.00\end{array}$ & $\begin{array}{c}1.13(1.06- \\
1.21) \\
1.00\end{array}$ & $\begin{array}{c}1.13(1.06-1.21) \\
1.00\end{array}$ & $\begin{array}{c}1.13(1.06- \\
1.21) \\
1.00\end{array}$ & $\begin{array}{c}1.13(1.06- \\
1.21) \\
1.00\end{array}$ \\
\hline $\begin{array}{l}\text { Years of full-time } \\
\text { education }\end{array}$ & & 1.07 (1.06-1.08) & 1.07 (1.06-1.08) & $\begin{array}{c}1.07(1.06- \\
1.08)\end{array}$ & $\begin{array}{c}1.07(1.06- \\
1.08)\end{array}$ & $1.07(1.06-1.08)$ & $\begin{array}{c}1.07(1.06- \\
1.08)\end{array}$ & $\begin{array}{c}1.07(1.06- \\
1.08)\end{array}$ \\
\hline $\begin{array}{l}\text { Main activity } \\
\text { Paid work } \\
\text { Unemployed /not in } \\
\text { labor force } \\
\text { Housework or other }\end{array}$ & & $\begin{array}{c}1.50(1.37-1.65) \\
.50(.45-.56) \\
1.00\end{array}$ & $\begin{array}{c}1.50(1.37-1.65) \\
.50(.45-.56) \\
1.00\end{array}$ & $\begin{array}{c}1.50(1.37- \\
1.65) \\
.50(.45- \\
.56) \\
1.00 \\
\end{array}$ & $\begin{array}{c}1.50(1.37- \\
1.65) \\
.50(.45-.56) \\
1.00\end{array}$ & $\begin{array}{c}1.50(1.37-1.65) \\
.50(.45-.56) \\
1.00\end{array}$ & $\begin{array}{c}1.50(1.37- \\
1.65) \\
.50(.45-.56) \\
1.00\end{array}$ & $\begin{array}{c}1.50(1.37- \\
1.65) \\
.50(.45-.56) \\
1.00\end{array}$ \\
\hline $\begin{array}{l}\text { Marital status } \\
\text { Married/civil partnership } \\
\text { Separated/widowed } \\
\text { Never in partnership }\end{array}$ & & $\begin{array}{c}1.22(1.12-1.33) \\
.96(.86-1.07) \\
1.00\end{array}$ & $\begin{array}{c}1.22(1.12-1.33) \\
.96(.86-1.07) \\
1.00\end{array}$ & $\begin{array}{c}1.22(1.12- \\
1.33) \\
.96(.86- \\
1.07) \\
1.00\end{array}$ & $\begin{array}{c}1.22(1.12- \\
1.33) \\
.96(.86-1.07) \\
1.00\end{array}$ & $\begin{array}{c}1.22(1.12-1.33) \\
.96(.86-1.07) \\
1.00\end{array}$ & $\begin{array}{c}1.22(1.12- \\
1.33) \\
.96(.86-1.07) \\
1.00\end{array}$ & $\begin{array}{c}1.22(1.12- \\
1.33) \\
.96(.86- \\
1.07) \\
1.00\end{array}$ \\
\hline Country-level $^{\mathrm{b}}$ & & & & & & & & \\
\hline $\begin{array}{l}\text { Arts students (\% tertiary } \\
\text { from all students) }\end{array}$ & & & $\begin{array}{c}1.20 \\
(1.04-1.37)\end{array}$ & & & & & \\
\hline RC index & & & & $\begin{array}{c}1.00 \\
(1.00-1.00)\end{array}$ & & & & \\
\hline $\begin{array}{l}\text { Writers and artists \% of } \\
\text { total employment) }\end{array}$ & & & & & $\begin{array}{c}1.98 \\
(1.04-3.78)\end{array}$ & & & \\
\hline
\end{tabular}




\begin{tabular}{|c|c|c|c|c|c|c|c|c|}
\hline $\begin{array}{l}\text { Exports of cultural goods } \\
\text { (1000 US\$ per capita) }\end{array}$ & & & & & & $\begin{array}{c}1.00 \\
(1.00-1.01)\end{array}$ & & \\
\hline $\begin{array}{l}\text { Imports of cultural goods } \\
\text { (1000 US\$ per capita) }\end{array}$ & & & & & & & $\begin{array}{c}1.01 \\
(1.00-1.01) \\
\end{array}$ & \\
\hline $\begin{array}{l}\text { Feature films ( } \mathrm{N} \text { per } \\
100,100 \text { population) }\end{array}$ & & & & & & & & $\begin{array}{c}1.00 \\
(1.00-1.00)\end{array}$ \\
\hline \multicolumn{9}{|l|}{ Variance estimates } \\
\hline Country intercept (SE) & $.35(.11)$ & $.33(.10)$ & $.25(.08)$ & $.21(.07)$ & $.27(.09)$ & $.24(.08)$ & $.14(.05)$ & $.27(.09)$ \\
\hline ICC (in percents) & $9.65 \%$ & $9.09 \%$ & $7.04 \%$ & $5.90 \%$ & $7.61 \%$ & $6.70 \%$ & $4.12 \%$ & $7.67 \%$ \\
\hline $\begin{array}{l}\text { \% change in country } \\
\text { intercept variance }{ }^{\mathrm{c}}\end{array}$ & - & $-5.7 \%$ & $-28.6 \%$ & $-40.0 \%$ & $-22.8 \%$ & $-31.4 \%$ & $-60.0 \%$ & $-22.8 \%$ \\
\hline
\end{tabular}

${ }^{\mathrm{a}}$ OR and 95\% CI for continuous variables expressed using two significant decimals

${ }^{\mathrm{b}} \mathrm{p}$ values for the statistically significant country-level variables: Arts students ( $\left.\mathrm{p}=.010\right)$, RC index ( $\left.\mathrm{p}=.001\right)$, Writers and artists ( $\left.\mathrm{p}=.038\right)$, Exports of cultural goods ( $\left.\mathrm{p}=.005\right)$, Imports of cultural goods $(\mathrm{p}<.001)$, Feature films $(\mathrm{p}=.039)$

cRelative to null model 
